\title{
The tutor in Primary Education and his/her intervention at the family level
}

(El tutor/a de Educación Primaria y su actuación en el ámbito familiar)

\author{
Nazaret Romero Muñoz \\ nromero@ujaen.es \\ Juan Francisco Porcel Fernández \\ Universidad de Jaén (España) \\ jfpf0001@ujaen.es
}

Fecha recepción: 01-03-2019

Páginas 74-82

Fecha aceptación: 20-05-2019

\section{Resumen.}

Este artículo trata sobre una propuesta tutorial enfocada a una alumna con necesidades específicas de apoyo educativo y cómo debería intervenir la comunidad educativa, entendiéndose como tal, la familia, el equipo docente, alumnado, etc., con el objetivo de orientarla sobre las necesidades que presenta dicha alumna y así establecer una relación de coordinación entre todos estos colectivos. Además, se reflejará el papel que va a desempeñar el tutor/a, equipo docente, profesionales de atención a la diversidad, equipo de orientación, familia y grupo de iguales, basándose en la legislación vigente. Para ello, se llevará a cabo una metodología constructiva, individualizada, significativa, abierta y flexible, con actividades desarrolladas individual y grupalmente para cubrir las necesidades que puedan surgir en ambos ámbitos.

Palabras clave: propuesta tutorial; comunidad educativa; tutor/a; coordinación.

\begin{abstract}
.
This article gives a brief account of a tutorial proposal focused on a student with special educational needs and how the educational community such as the family, the educational team, the students, and so on, should act in order to guide this community about the needs the pupil has and, therefore, establish a coordination relationship between all these groups. Furthermore, we will deal with the role that the tutor is going to play, the faculty, professionals specialized on diversity, guidance team, family and peer groups, on the basis of the current law. For that purpose, we will carry out a constructive, personalized, significant, open and flexible methodology, with activities developed individually and in groups so that we can meet the needs which can arise in both fields.
\end{abstract}

Keywords: tutorial proposal; educational community; tutor; coordination 


\section{Introduction.}

The loss of essence of a democratic society, in which the individual freedom is broken, on many occasions, must be regained in the school context. If our aim as teachers is to educate future adults so that they can integrate into society and participate democratically in it, the educational community, together with parents, will be the groups in charge of meeting these needs. We consider tutoring as an educational resource used in order to show students strategies for integration into society as well as for facilitating the comprehensive development of the individual.

\section{Justification.}

The success of a Tutorial Action Plan is connected with the way of raising awareness of this plan usefulness, transmitting information and the action method when covering traits of each student. The aim of this work is to reflect the importance of a tutoring established by the teacher, the tutor, in his commitment to guide continuously and individually students throughout their schooling career owing to the educational institution is in charge of analysing and foreseeing any problem among students. But not only teachers take on this responsibility, relatives are the main source of information, therefore they must participate and cooperate entirely with the Tutorial Action Plan helping and liaising with the professional team.

\section{Theoretical framework.}

In order to get a better understanding of the Tutorial Action Plan concept, we must begin by knowing broadly speaking its development throughout history.

Tutoring concept.

According to Blanchard, Muzás (1999), tutoring is one of the most important educational processes carried out by teachers considering that its goal is to integrate the work conducted by the educational team with each student, encouraging individualisation and learnings, as well as the complete development of individuals. This tutorial action is developed in the centre and includes different approaches. This tutorial action has the following characteristics:

$>\quad$ It takes into account diversity of the school: tutoring responds to plurality because each student has his own learning speed, not being considerated as passive subjects.

It is based on the constructivist methodology, being an active learning and with the involvement of peers, creating an affective and motivating context.

$>\quad$ It offers tools for the teacher-tutor, so as to meet students' needs.

$>\quad$ It exerts an integrating role of the class group.

Tutor's role in primary education. 
As believed by Muller (2007), the tutor's role is essential in these levels because he provides with interviews, either individual ones or in groups, not only for pupils or parents, but also with other teachers, who can be also tutors, setting in motion functional learning processes and those enriching individuals or groups. The tutor has to boost a climate of communication among participants, creating a relationship between tutor and pupil. In this relationship, the tutor must be in charge of generating a context where feelings, ideas, representations of a mutual emotional bond can be voiced.

Special Educational Needs.

The first concepts related to students who show more significant difficulties regarding the access to learnings, typical of schoolmates at their age, are carried out by Brennan. Lázaro (2002), mentions that Brennan (1988)"makes a distinction between individual differences in order to learn that they are attached to any student and must be solved by regular means that the teacher has at his disposal, and that learning difficulties which have students with special educational needs, cannot be sort out without extra help or resources, either educational, psychological or medical." (p. 24).

In accordance with Fernández, Clavijo, Silva and Bernet (2002), Mayor (1992) claims that "the fact that a student demands special educational needs means that he owns some learning problem throughout his schooling, needing a more specific attention and greater educational resources of those required for schoolmates at his age". (p. 30)

Family and school.

As stated by Ejido (2015), parents' role at school is essential in a modern and democratic society demanding the involvement of teachers, students, parents and other social demands. Studies carried out in the half of the XXth century, represented the link existing between family features and children's academic results. These studies argued that the family structure, social group, cultural level, socio-economic level, and the like, could have some influence on students' school success or failure. Thanks to evolutionary psychology as well as social psychology in the 70s, there was a change of mind concerning influences previously mentioned. With the Bronfenbrenner's work $(1979,1986)$, the author declares that it cannot be only understood because of cultural and social factors belonging to the family, but also it must be taken into account the background in which the child unfolds.

Coordination family school.

According to Comellas (2009), the importance of the relation between these two groups is essential and must promote a learning based on interest, confidence and motivation. The school must provide families with the necessary conditions so that they can attend or collaborate, communicate through class meetings, individual 
meetings and so on. The author highlights that the bonds between the two groups must not have just one purpose, that is, to analyse children's achievement or solve conflicting situations.

As believed by Romero (2010), the family has a fundamental role throughout the children's training period on the grounds that it is the closest community to them and, therefore, can supply essential information to the teacher team for a future guidance. This information is vital since it can lead the tutor towards possible measures that the pupil's needs can require. Making the family aware is important in order to integrate them into the school context, for instance, in activities developed at school, cooperating in them as an advantageous method for their children's teaching-learning process. The significance of the idea that the family and school are figures which contribute to socialisation will help both entities to work jointly for social integration of students, contributing to develop the skill dealing with personal autonomy.

Tutorial Action Plan.

In accordance with Pérez (2011), drawing a tutorial action plan is connected with the necessity for carrying out the most individualized attention possible to meet the student's needs. In order to develop a proper tutoring, teacher training will play an essential role due to the fact that they will need useful knowledge for processes demanding tutorial action such as planning, resources used, knowing how to coordinate the involvement not only of teachers but also families, monitoring strategies, and the like.

Proposals for a Tutorial Action Plan.

As maintained by Redondo, Vale, Navarro, Madrigal and Parras (2009), they underline the necessity that teachers being "tutors" benefit from a school counselor during the tutorial practice. For this activity is needed not to exist a hierarchical figure between the teacher "tutor", school counselor, and the student, making use of empathy and respect as skills.

According to Blasco, Pérez (2012), the tutor's role in tutorial activity is to deal with learning disabilities that the student can have in his curriculum and assess his achievements at the end of each level in Primary Education on the basis of reports from other teachers. Moreover, the tutor will have to be supported by the Educational and Psychopedagogical Guidance Teams so as to accomplish the goals proposed in the tutorial plan. In the case that the student shows specific needs for educational support, the tutor must coordinate with the teams previously mentioned as well as the therapeutic pedagogy teacher to establish the appropriate significant curricular adaptations or the most suitable measures for him.

Tutorial Action Plan for students with specific needs for educational support.

Castillo, Bretones (2014) claim that a figure which could serve for being the link in an educational community, that is to say, teachers and families, may be the social 
educator. This figure benefits from a series of tools in this educational community promoting relationships between both groups as well as creating a more committed and enriching collaborative climate.

As stated by the authors previously mentioned, the social educator will be involved in the educational and psychopedagogical guidance team improving links between families belonging to students with serious integration problems, implementing measures like monitoring truancy or an improvement in conflict resolution together with teachers. For parents having children with some kind of disability, the social educator will carry out training programmes for these parents as well as socioeducational programmes with the purpose of developing the personal autonomy skill.

According to Estévez, Jiménez, Musitu, Martínez, Guarinos, Cava, Buelga, Estévez, Moreno (2016), they explain that once detected the pupil's needs, the objectives from the Tutorial Action Plan are specified. In order to accomplish each goal, they plan a series of programmes which contain the organization and timing from the faculty. As believed by these authors, programmes must cover the needs found in the educational community and involve it in the Tutorial Action Plan, being adapted to the students' realistic and functional criteria.

\section{Methodology.}

In accordance with Andreu (2013), the tutor's role in the Tutorial Action Plan will be to guide and advise the student body in an inclusive way and prepare them to play their future role in society. For the author, the tutor will carry out the following methodology:

1) Assigning each student a role throughout a certain period of time in order to control his attendance and thus encourage him to attend class.

2) The distribution of the pupil in class will be essential for integration and communication with other classmates, changing his place periodically. In this part we work controlling children's behaviour, detection of children with hearing problems, learning problems, and so on.

3) In the Tutorial Action Plan, the most suitable rules for the group or individually will be designed, for instance: how to leave class, order and cleaning regarding the classroom, and the way of assessing every child, being that individualized and continuous.

Personal proposal of a Tutorial Action Plan.

In my proposal of a Tutorial Action Plan, I am going to focus on a real case consisting of a girl with functional dyslalia. In Gonzáles's view (2008), functional dyslalia is one of the most common disease in our classrooms due to the fact that this disease affects articulation of speech, in particular, in pre-school and primary education, causing replacement, omission, insertion or distortion of phonemes. The most usual disorders associated with dyslalia are: aphonia (complete loss of voice), dysphonia 
(disturbance of voice because of an organic disorder or a bad use of voice), laryngophonies (larynx dysphonias) and rhinophonies (resonance alteration). The functional dyslalia can cause problems in the communicative process in the child's daily life, behavioural changes, difficulties in the process of reading and writing, and the like. These problems can be worsened due to the lack of information or training not only of parents but also the teaching team.

Now we will analyze the features having this pupil in her family and school background.

Socio-family background.

The pupil lives in a socioculturally deprived area from her locality, whose economic and cultural growth is rather limited. Her family environment is highly broken. Apart from her grandmother, the pupil is also being brought up by an uncle and an aunt, who have four sons and one daughter, who is 9 years old and from her birth she suffers from a deep bilateral hearing impairment, so, it is a pre-linguistic type, and has been enrolling a little while ago.

Pupil's school situation.

The pupil is enrolled in a Primary Education school in the first level of Primary Education. Throughout her schooling, she has attended class irregularly, with certain periods of high absenteeism.

Initial evaluation.

According to her psychopedagogical evaluation:

The pupil shows a great number of articulatory difficulties with lots of mistakes: omission, replacement, inversion, distortion,... in most of the phonemes ("functional dyslalia") probably caused by the influence of the sociocultural deprived environment in which she lives, and it leads her to show a practically unintelligible speech. Her intellectual disability in the language is provoked by a very deficient background stimulation, having hurt her linguistic-communicative development.

Methodology.

In our Tutorial Action Plan the methodology will be drawn with the main purpose of integrating the child into the usual classroom. To this end, the guidance team will establish a role-playing game adapting it to the characteristic of the classroom as well as the child's features, improving motivation, making use of the game as an integrating element and arousing the child's interest by attending class (active approach). The child's distribution in the classroom will be very important, sitting down with different classmates and this way to improve her relationship and communication with peers, forming a small working group (cooperative learning). With this approach we try to detect not only possible disabilities that the child has with her classmates (behaviour, communication...), but also some other impairment or difficulty (deafness, blindness, and so on). Furthermore, the Tutorial Action Plan will also reflect how the tutor must raise awareness and prepare students of the behaviour with this pupil and let them know about her disease, providing them with information. The methodology 
will be designed on the basis of students' diversity, making decisions about the different learning speed that the child has.

Coordination family and school.

The educational community (family, counselor, tutor...) every two months, will gather once in order to report on the pupil's progress in the different backgrounds. The involvement of the family in their daughter's guidance is essential because it creates an environment favouring the teaching-learning process and helping both collectives to work jointly, growing up the child in a climate of interest, confidence and motivation and not in a disagreement environment. The tutor will be responsible for arranging the meetings holding together family and school, informing the educational community all the time. The counselor is in charge of advising the educational community in these meetings on the integration of measures or the learning resources required concerning the pupil's diversity, helping in the Tutorial Action Plan planning. The pedagogical coordination technical team will commentate how they are going to set the procedures for pedagogical intervention and suggest the approach of the measures and techniques for functional dyslalia. The family must keep within the decisions made as well as the management proposed by the professional team so as to deal with the pupil with functional dyslalia.

As a way of communicating everyday between parents and the centre, an appoitment book will be used, which will contain significant notes that must be known by both collectives such as the attitudes shown, some activity of interest or simply reward any positive fact. In the case that the pupil is helped by some professional external to the centre, like a speech therapist, this notebook will be used as an informative way.

Activity schedule.

Once detected the pupil's needs, the situation in which she unfolds and the goals she must put into practice, activities and tools will be classified into two categories: those aimed at the class group and activities more individualized for the pupil in the Centre Plan. Activities are designed by the pedagogical coordination technical team and applied by the Therapeutic Pedagogy/ Hearing and Speech Teacher with the tutor's help regarding the goals to accomplish.

The centre plan focused on the pupil, will be examined and applied by each pedagogical coordination technical team, modifying the appropriate measures such as the assessment criteria, approaches, improving the functioning of the education project, and the like. The tutor will be responsible for notifying the family of the pupil's progress or changes that have happened. The pedagogue team will also guide the faculty lacking of information related to the pupil.

\section{Conclusion.}

The school must provide the educational community with an answer regarding the possible problems or difficulties that students can suffer. For that purpose, the school 
contemplates a tutorial action plan which is drawn by the tutor. This tutorial plan should meet the students' needs taking into account their skill level, socio-economic level, and thus set the targets to work. The tutor must be the figure in charge of timing and organization of the tutorial plan due to the fact that he is the person who spends most of the time with the pupils, therefore, who most knows about their needs.

The role of fathers and mothers is also essential because on many occasions is a primordial source of information for the teacher; hence the importance of the relationship which should exist between the tutor and the family. The teacher must be aware that he also learns from the parents because they are after all who most know kids, being able to provide ideas or motivating projects for their children. If we transfer this to a child with special educational needs, between parents and teachers there should be a very significant relationship and this way supply the child to technical assistance, support, resources, type of communication... as agreed as possible between the school and home, avoiding disagreements and not confusing the child.

\section{Bibliography.}

Andreu, B. (2013). Programación didáctica. $1^{\circ}$ curso de Educación Primaria. Alicante: Club Universitario.

Blanchard, M., Muzás, Ma.D. (1999). Plan de acción tutorial en educación secundaria. Elaboración, desarrollo y materiales. Madrid: Narcea, S.A. de ediciones.

Blasco, P., Pérez, A. (2012). Enfoques y aplicaciones prácticas en orientación y acción tutorial. Valencia: Nau Libres (Edicions Culturals Valencianes).

Bretones, E., Castillo, M. (2014). Acción Social y Educativa en contextos escolares. Barcelona: UOC (Oberta UOC Publishing, SL.).

Comellas, Ma . J. (2009). Familia y escuela: compartir la educación. Barcelona: Editorial Graó de irif, S.L.

Ejido, I. (2015). Las relaciones entre familia y escuela .Una visión general. Revista del consejo escolar del estado.Volumen 4. № (7), (pág. 11-12).

Estévez, E., Jiménez, T., Musitu, G., Martínez, B., Guarinos, M., Cava, Ma.J., Buelga, S., Estévez, J. F., Moreno, D. (2016). Intervención psicoeducativa en el ámbito familiar, social y comunitario. Madrid: Ediciones Paraninfo, S.A.

Fernández, G., Silva, L., Clavijo, R., Bernet, J. (2002). Auxiliares de Educación Especial Temario General. E-book. Sevilla: Mad, S.L.

Gonzáles, J.N. (2008). Alteraciones del habla en la infancia. Buenos Aires: Editorial Médica Panamericana. 
Lázaro, F. (2002). Escuela compartida para alumnado con necesidades educativas especiales intensivas. Granada: Mad, S.L.

Muller, M. (2007). Docentes tutores. Buenos Aires: Bonum.

Pérez, Ma . P. (2011). Innovación metodológica y espacio europeo de educación superior. Experiencias docentes en el ámbito del derecho. Madrid: Dykinson, S.L.

Redondo, S., Vale, P., Navarro, E., Madrigal, A. Ma., Parras, A. (2009). Orientación educativa: fundamentos teóricos, modelos institucionales y nuevas perspectivas. Madrid: Secretaría general técnica. Subdirección General de Documentaciones y Publicaciones.

Romero, Ma . J. (2010). Familia y escuela. Sevilla: Wanceulen editorial, S.L.

González, J.A.T., Fernández, A.H., De Barros, C. (2013). Aspectos fundamentais da pesquisa científica. Granada: Ediciones Adeo.

Haddad, S., Di Pierro, M.C. (2000). Escolarização de jovens e adultos. São Paulo: Revista Brasileira de Educação v.14, n.3, p.108.

Lei de Diretrizes e Bases. (1996). Lei no 9.394, de 20 de dezembro de 1996. Presidência da República. Casa Civil. Brasília: Subchefia para Assuntos Jurídicos.

Roraima-Secad. (2010). Proposta da Rede Pública Estadual Para a Educação de Jovens e Adultos. Boa Vista: Secretaria Estadual de Educação e Cultura.

Santos, H.E.A. (2000). Fatores de crescimento de Roraima, 1970/1998. Dissertação de mestrado 197 p. Porto Alegre: Universidade Federal de Rio Grande do Sul.

Santos, N.P.D. (2004). Políticas Públicas, economia e poder: o Estado de Roraima entre 1970 e 2000. Tese de doutorado 356 p. Belém: Universidade Federal do Pará. 